\title{
Drivers of fire occurrence in a mountainous Brazilian cerrado savanna: Tracking long-term fire regimes using remote sensing
}

\author{
Swanni T. Alvarado ${ }^{\mathrm{a}, \mathrm{b}, *}$, Tamires Fornazari ${ }^{\mathrm{a}}$, Andresa Cóstola ${ }^{\mathrm{a}}$, \\ Leonor Patricia Cerdeira Morellato ${ }^{\mathrm{b}}$, Thiago Sanna Freire Silva ${ }^{\mathrm{a}}$ \\ a Ecosystem Dynamics Observatory, Universidade Estadual Paulista (Unesp), Instituto de Biociências, Phenology Laboratory, Rio Claro, Av. 24A, 1515, Rio \\ Claro, SP, 13506-900, Brazil \\ ${ }^{\mathrm{b}}$ Phenology Laboratory, Universidade Estadual Paulista (Unesp), Instituto de Biociências, Campus Rio Claro, Av. 24A, 1515, Rio Claro, SP, 13506-900, Brazil
}

\section{A R T I C L E I N F O}

\section{Article history:}

Received 28 June 2016

Received in revised form

25 November 2016

Accepted 24 February 2017

Available online 27 March 2017

\section{Keywords:}

Burned area

Seasonality

Fire frequency

Ignition season

Moisture limitation

Fuel limitation

Biomass

\begin{abstract}
A B S T R A C T
Fire is a natural disturbance in savannas, and defines vegetation physiognomy and structure, often influencing species diversity. Fire activity is determined by a wide range of factors, including long and short term climatic conditions, climate seasonality, wind speed and direction, topography, and fuel biomass. In Brazil, fire shapes the structure and composition of cerrado savannas, and the impact of fire on vegetation dynamics is well explored, but the drivers of variation in fire disturbance across landscapes and over time are still poorly understood. We reconstructed 31 years of fire occurrence history in the Serra do Cipó region, a highly-diverse cerrado landscape, located in the southern portion of the Espinhaço mountain range, state of Minas Gerais, Southeastern Brazil. We mapped burn scars using a time series of Landsat satellite images from 1984 to 2014. Our questions were 1) How does fire occurrence vary in time and space across the Serra do Cipó cerrado landscape? 2) Which climatic drivers may explain the spatial and inter-annual variation in fire occurrence on this landscape? 3) Is fire occurrence in this cerrado landscape moisture-limited or fuel-limited? We evaluated the inter-annual variation and distribution of burned areas, and used linear models to explain this variation in terms of rainfall amount (determinant of fuel load production), seasonal rainfall distribution (determinant of dry fuel availability), abnormality of precipitation (Standardized Precipitation Index - SPI), and vegetation type (Enhanced Vegetation Index EVI). Contrary to our expectations, annual rainfall volume was weakly and negatively correlated with burned area, and the strongest predictor of burned area was drought during the ignition season. The length of the dry season and the distribution of rain along the season determined ignition probability, increasing fire occurrence during the driest periods. We conclude that the mountain cerrado vegetation at Serra do Cipó has a moisture-dependent fire regime, in contrast to the fuel-dependent fire regimes described for African savannas. These findings imply that savannas at different continents may have different recovery and resilience capabilities when subjected to changes in the fire regime, caused by direct anthropogenic activities or indirectly through climatic changes. The possible effects of these changes on cerrado landscapes are still unknown, and future studies should investigate if currently observed fire regimes have positive or negative impacts on vegetation diversity, recovery, resilience and phenology, thus helping managers to include fire management as conservation measure.
\end{abstract}

(C) 2017 Elsevier Ltd. All rights reserved.

\section{Introduction}

Savannas are characterized by a continuous grass layer with scattered trees and shrubs, growing under hot and seasonally dry

\footnotetext{
* Corresponding author at: Ecosystem Dynamics Observatory, Universidade Estadual Paulista (Unesp), Instituto de Geociências e Ciências Exatas, Departamento de Geografia, Campus Rio Claro, Av. 24A, 1515, Caixa postal 178, Rio Claro, SP, 13506-900, Brazil.

E-mail address: swanni_ta@yahoo.es (S.T. Alvarado).
}

climatic conditions. Covering $20 \%$ of the terrestrial surface, savannas are present in Africa, Asia, Australia and South America (White et al., 2000). The structure and diversity of savanna vegetation are determined by the interaction of moisture availability, soil fertility, temperature, and an equilibrium between the proportion of woody and grass biomass and the fire regime (Lehmann et al., 2014). Fire is a natural disturbance in savannas, and is considered the key component in defining their physiognomy and structure, influencing species abundance and diversity (Bond et al., 2005; Bond and Keeley, 2005). Fire activity in savannas is determined by a wide range of factors, including long and short term climatic con- 
ditions, climate seasonality, short-term variations in wind speed and direction, topography, and fuel biomass (Cochrane and Ryan, 2009; Trollope et al., 2002). In all savannas across the world, these natural fire regimes have been increasingly altered by human activities, either through direct land use practices or indirectly through changes in climate (Archibald, 2016).

Annual rainfall seems to be one of the main drivers of interannual variability in fire occurrence, and is often one of the main input variables in predictive fire models (Aldersley et al., 2011; Archibald et al., 2009; van der Werf et al., 2008). In a gradient from mesic to arid ecosystems, fire activity can have predictable spatial patterns according to the interaction between climate conditions (moisture) and fuel availability (biomass) (Bradstock, 2010; Krawchuk and Moritz, 2011; Meyn et al., 2007; van der Werf et al., 2008). In biomass-rich areas, where fuel is always available for burning during the fire season, fuel moisture conditions rather than fuel amount represent the main limitation of fire activity (Krawchuk and Moritz, 2011). On savannas, fire activity is more complex and can vary across continents (Lehmann et al., 2014). In South America, where savannas are found in regions with up to $2500 \mathrm{~mm}$ of annual precipitation, fire activity is closely associated with climate seasonality (Lehmann et al., 2011). Conversely, African savannas usually receive less than $1000 \mathrm{~mm}$ of annual precipitation, and fire is less frequent (Lehmann et al., 2011) and associated with fuel biomass availability and connectivity (Krawchuk and Moritz, 2011).

In Brazil, the cerrado savannas originally covered an area of $\sim 2$ million $\mathrm{km}^{2}$, corresponding to about $25 \%$ of the Brazilian territory (Durigan and Ratter, 2016). Recent estimates show that only $41 \%$ $\left(\sim 833000 \mathrm{~km}^{2}\right)$ of the original cerrado cover still remain as native vegetation cover (Soares-Filho et al., 2014). Overbeck et al. (2015) estimate a loss of $92,712 \mathrm{~km}^{2}$ of natural cerrado areas to agricultural uses, between 2002 and 2009, showing that current deforestation rates are still high, and increasingly leading to landscape fragmentation and loss of ecosystem function. The cerrado is currently one of the most threatened vegetation types in South America, with only $7 \%$ of its present cover under legal protection (Soares-Filho et al., 2014). These threats are mostly derived from direct human activities, especially from the dramatic changes in land use promoted by large-scale agriculture (soybean, rice, corn, and cotton monocultures), livestock ranging, and mineral extraction (Klink and Moreira, 2002; Overbeck et al., 2015). Recent research has underscored the importance of the cerrado, emphasizing its high diversity. Over 13,127 plant species have been recorded within this biome, on par with the 13,216 plant species reported for the Amazon region (Overbeck et al., 2015). Moreover, a high degree of endemicity has been observed for plants and animals (Silva and da Bates, 2002; Silveira et al., 2016).

In Brazil, fire shapes the structure and composition of cerrado vegetation (Coutinho, 1982; Loiola et al., 2010; Silva et al., 2013). Fire can affect the reproductive success of cerrado plant species by influencing seed germination (Fichino et al., 2016; Fidelis et al., 2016) and flowering (Fidelis and Blanco, 2014; Hoffmann, 1998), and also determines trait variability in cerrado plants (Dantas et al., 2012; Hoffmann et al., 2012a). Nevertheless, human-induced fire is considered one of the most significant threats to this ecosystem (Pivello, 2005). Changes in the natural fire regime can lead to increased woody encroachment (Hoffmann, 1999) and invasive grasses (Durigan et al., 2007; Gorgone-Barbosa et al., 2016), which in turn change fire behavior and increase their severity (GorgoneBarbosa et al., 2013).

The role of fire as the main driver of vegetation dynamics in the Brazilian cerrado, maintaining the equilibrium between grasses and trees, has been demonstrated elsewhere (Dantas et al., 2013; Hoffmann et al., 2012b, 2009). However, studies of the drivers of temporal and spatial variation in fire occurrence have been limited to coarse global models, seeking to explain the drivers limiting savanna and fire occurrence across continents (Krawchuk and Moritz, 2011; Lehmann et al., 2014, 2011; van der Werf et al., 2008). Quantifying fine-scale and long-term changes in the temporal and spatial patterns of fire occurrence in the cerrado, and its attributes (intensity, seasonality, size, and return time), is therefore crucial for understanding the driving forces of changes in fire dynamics, and assist land management and conservation practices for cerrado landscapes.

Retrospective studies based on historical remote sensing have allowed the reconstruction of fire history on ecosystems for most parts of the world (Csiszar et al., 2004; Wittkuhn and Hamilton, 2010). Two basic types of information can be derived from remote sensing to estimate fire affected areas: a) the presence of active fires, using thermal remote sensing, and b) the identification of burn scars or burned areas, using optical data. The near-continuous Landsat data record, available since 1984 with a spatial resolution of $30 \mathrm{~m}$ and temporal resolution of ca. 16 days, offers the best trade-off between temporal coverage and spatial resolution, making it ideal for mapping fire scars in savanna landscapes from local to regional scales (Hudak and Brockett, 2004; Russell-Smith et al., 1997).

In the present study, we reconstructed 31 years of fire occurrence history in the Serra do Cipó region, a hyperdiverse mountainous cerrado landscape in Brazil, based on the spatial and temporal analysis of burn scars mapped using Landsat satellite images from 1984 to 2014 . We also related observed fire frequencies to the possible drivers of fire occurrence in cerrado to explain fire patterns and their variation across time. Our questions were 1) How does fire occurrence vary in time and space across the Serra do Cipó cerrado landscape? 2) Which climatic drivers may explain the spatial and inter-annual variation in fire occurrence on this landscape? 3) Is fire occurrence in this cerrado landscape moisture-limited or fuel-limited?

\section{Methods}

\subsection{Study area}

We studied the area comprised by the Serra do Cipó National Park (SCNP) and the enclosing Morro da Pedreira Environmental Protection Area (MP-EPA), located about $100 \mathrm{~km}$ northeast of the city of Belo Horizonte, state of Minas Gerais, Brazil (Fig. 1). Both areas are usually referred together as "Serra do Cipó", and comprise the southern portion of the Espinhaço range, the largest interior mountain range in Brazil (Giulietti, 1997). The SCNP has an area of $316.3 \mathrm{~km}^{2}$, and was created in 1984. The MP-EPA has an area of $1001.1 \mathrm{~km}^{2}$, and was created in 1990 , to provide a buffer zone to the protected ecosystems within the park. Between 2002 and 2004, conservation policies resulted in the progressive reduction of livestock herding in the SCNP, culminating with a virtually livestock-free status in 2008 (França and Ribeiro, 2008).

The climate of the region is warm subtropical with dry winters and hot summers, and markedly seasonal. Average annual rainfall is ca. $1400 \mathrm{~mm}$, with a rainy season ranging from $75 \mathrm{~mm}$ to $340 \mathrm{~mm}$, from October to April (monthly rainfall $>60 \mathrm{~mm}$ ), and a dry season ranging from 7 to $32 \mathrm{~mm}$, from May to September (monthly precipitation $<40 \mathrm{~mm}$ ) (ANA 2016). Average daily maximum and minimum temperatures are $33^{\circ} \mathrm{C}$ and $28^{\circ} \mathrm{C}$ for the hottest month (February) and $13^{\circ} \mathrm{C}$ and $7^{\circ} \mathrm{C}$ for the coldest months (July). The topography of the study area is rugged and predominantly mountainous, with elevations ranging from $750 \mathrm{~m}$ above sea level (a.s.l) to $1670 \mathrm{~m}$ a.s.l. (Ribeiro and Figueira, 2011).

Within the SCNP and MP-EPA, vegetation occurring below $900 \mathrm{~m}$ altitude includes a mosaic of forest-like formations ("Cerradão"), lowland cerrado vegetation with varying proportions of herbaceous and woody cover ("Cerrado sensu stricto", "Campo Cerrado" and 

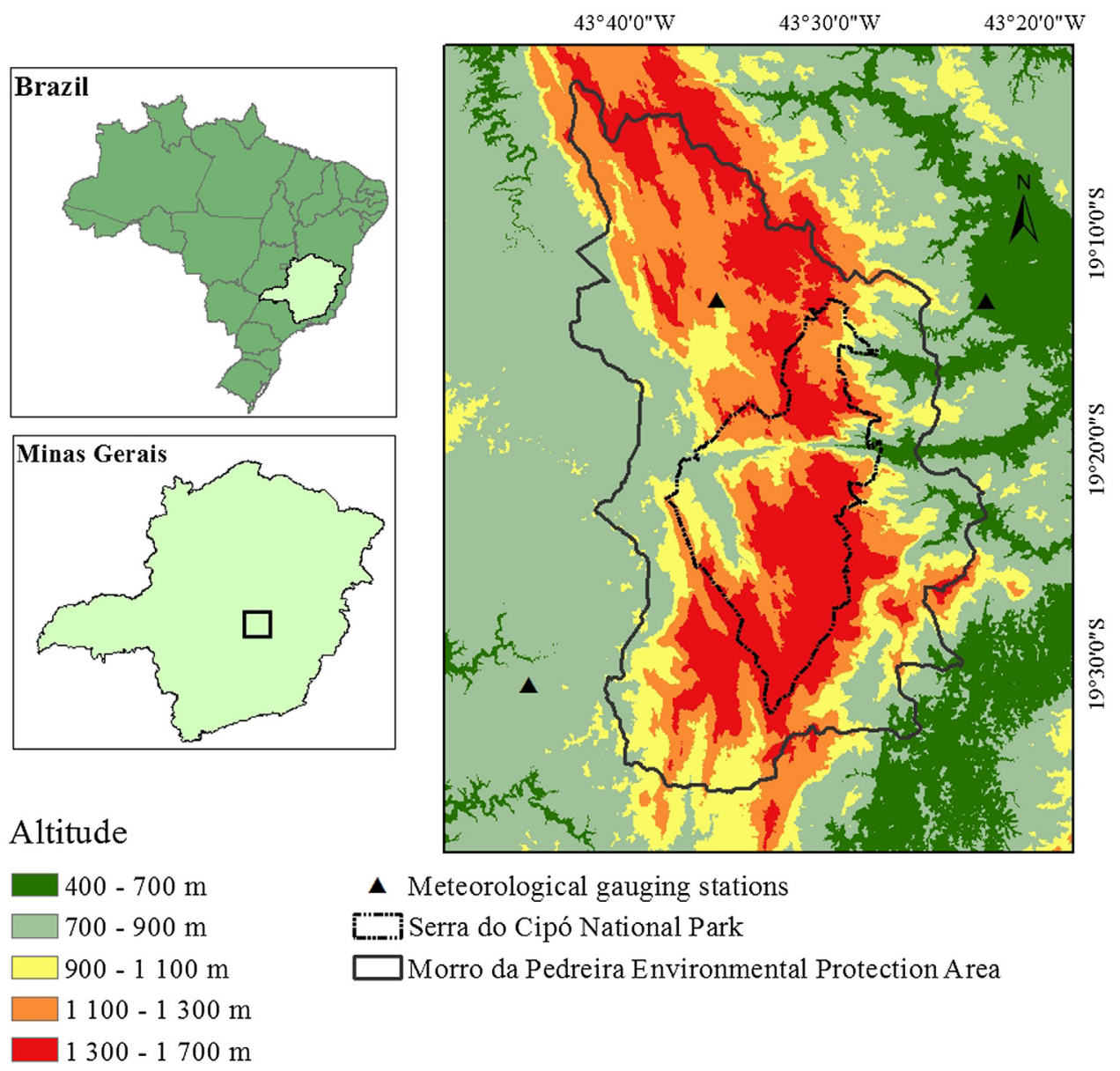

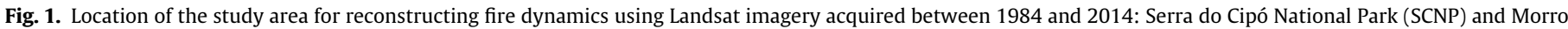

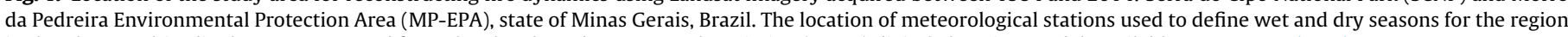
is also shown. Altitudinal ranges extracted from the Shuttle Radar Topography Mission (SRTM) digital elevation model, available at www.earthexplorer.org.

"Campo Sujo"), and open grasslands ("Campo Limpo") all considered as part of the Cerrado sensu lato classification (Oliveira-Filho and Ratter, 2002; Ratter et al., 1997). Tropical seasonal forest(“Mata Atlântica") occurs mostly to the East, or as small islands or patches ("capões de mata") (Fernandes, 2016). This mosaic also includes the campo rupestre fomation (Silveira et al., 2016; Fernandes 2016) comprised by rocky, sandy or waterlogged grasslands and rocky outcrops occurring above $900 \mathrm{~m}$ altitude, and the campos de altitude, high elevation grasslands occurring at the mountaintops. These latter formations are the prevalent vegetation cover in the Espinhaço range and are also considered as Cerrado sensu lato (Oliveira-Filho and Ratter, 2002; Ratter et al., 1997; Fernandes, 2016).

\subsection{Environmental data}

Daily precipitation was obtained from the Brazilian National Water Agency (ANA 2016) for the entire study period (1984-2014). Data from three meteorological gauging stations was used for the climatological analysis (Fig. 1): one station located on the eastern side of the mountain (Jaboticatubas), one on the western side (Morro do Pilar), and one station centered on the SCNP (Vau da Lagoa). The data from all three stations was averaged to address the east-west precipitation changes caused by topography.

\subsection{Remote sensing data}

To reconstruct the fire history of the studied area, we used the existing record of Landsat 5 Thematic Mapper (TM), Landsat 7
Enhanced Thematic Mapper Plus (ETM+) and Landsat 8 Operational Land Imager (OLI) images from 1984 to 2014 (Table 1), obtained from the Earth Explorer database of the United States Geological Survey (USGS, earthexplorer.org). The entire study area is included within path 218 , row 73 of the WRS-2 Landsat reference system. All images were downloaded as Landsat Climate Data Record (CDR) products, which are already corrected for geometric and atmospheric effects, and include a cloud cover mask generated by the fmask algorithm (Zhu et al., 2015). All images were converted to the Geographic Coordinate System, datum WGS84.

The ETM+ sensor had a failure on its Scan Line Corrector mirror in 2003, resulting in systematic data loss across each image (SLC-off imagery). Between the decommissioning of Landsat 5 TM in November 2011, and the start of operations of Landsat 8 OLI in April 2013, ETM+ SLC-off imagery was the only source of Landsat data available. To minimize the impact of data loss during this period, we complemented ETM+ acquisitions with data from the Burned Area product (MCD45A1v5) of the Moderate Resolution Imaging Spectroradiometer (MODIS) sensor, derived from a synthesis of daily surface reflectance data corrected for atmospheric effects (MOD09GQK) over a period of one month. Each $500 \mathrm{~m}$ pixel contains information on the presence or absence of burned areas, and the approximate date of the observed fire during the analyzed month (Table 1).

To estimate the vegetation type burned, we used the Enhanced Vegetation Index (EVI) derived from a time series of the MOD13Q1 MODIS data product (Vegetation Indexes) over the 2000-2014 vegetation period. EVI was proposed by Liu and Huete (Liu and 
Table 1

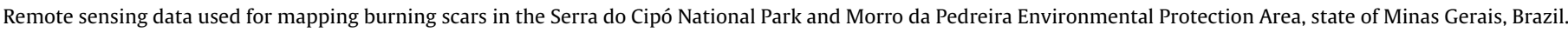

\begin{tabular}{|c|c|c|c|c|}
\hline Satelite & Sensor & Spatial resolution & Used Bands & Availability \\
\hline Landsat 5 & TM & $30 \mathrm{~m}$ & $5-4-3$ & 1984-early 2013 \\
\hline Landsat 7 & ETM+ (SLC-off) & $30 \mathrm{~m}$ & $5-4-3$ & 1999-2003 (before SLC failure) \\
\hline Landsat 8 & OLI & $30 \mathrm{~m}$ & $6-5-4$ & May 2013- present \\
\hline MODIS(MCD45A1v5 product) & Terra and Aqua & $250-500 \mathrm{~m}$ & $1-2$ & April 2000-present \\
\hline MODIS (MYD14 product) & Aqua & $1 \mathrm{~km}$ & $1-2$ & $2002-$ present \\
\hline MODIS (MOD13Q1 product) & Terra and Aqua & $250 \mathrm{~m}$ & $1-2$ & April 2000-present \\
\hline
\end{tabular}

Table 2

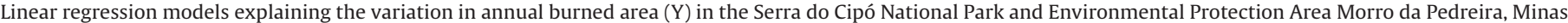
Gerais, Brazil.

\begin{tabular}{|c|c|c|c|c|c|c|}
\hline Simple regression & & $n$ (years) & Regression equation & $\mathrm{R}^{2}$ & $p$ & AIC \\
\hline Annual & Annual rainfall & 31 & $\begin{array}{l}\mathrm{Y}=244.86-0.09 \times \text { Annual } \\
\text { rainfall }+\mathrm{e}\end{array}$ & 0.09 & 0.110 & 352.6 \\
\hline Annual & Annual days of rain & 31 & $\begin{array}{l}\mathrm{Y}=358.56-2.42 \times \text { Annual Days of } \\
\text { rain }+\mathrm{e}\end{array}$ & 0.25 & 0.004 & 346.5 \\
\hline Multiple regression & & $n$ (years) & Regression equation & $\mathrm{R}^{2}$ & $p$ & AIC \\
\hline Rainfall & $\begin{array}{l}\text { Ignition + Growing } \\
\text { season }\end{array}$ & 31 & $\begin{array}{l}\mathrm{Y}=278.56-0.054 \times \text { Growing } \\
\text { rainfall }-0.25 \times \text { Ignition rainfall }+\mathrm{e}\end{array}$ & 0.19 & 0.050 & 350.9 \\
\hline Days of rain & $\begin{array}{l}\text { Ignition + Growing } \\
\text { season }\end{array}$ & 31 & $\begin{array}{l}\mathrm{Y}=368.18-1.05 \times \text { Days of rain in } \\
\text { Growing season }-4.89 \times \text { Days of } \\
\text { rain in Ignition season }+\mathrm{e}\end{array}$ & 0.38 & 0.0013 & 342.8 \\
\hline $\begin{array}{l}\text { Days of rain and EVI } \\
\quad(2003-2014)\end{array}$ & $\begin{array}{l}\text { Days of rain in Ignition } \\
\text { season }+ \text { Growing } \\
\text { season + EVI }\end{array}$ & $12^{*}$ & $\begin{array}{l}\mathrm{Y}=575.37+0.19 \times \text { Days of rain in } \\
\text { Growing season }-3.45 \times \text { Days of } \\
\text { rain in Ignition } \\
\text { season }-0.10 \times \mathrm{EVI}+\mathrm{e}\end{array}$ & 0.43 & 0.190 & $133.6^{*}$ \\
\hline
\end{tabular}

* AIC values are not comparable for models with different numbers of observations.

Huete, 1995) to compensate the limitations of the Normalized Difference Vegetation Index (NDVI) regarding soil background and atmospheric interference, and is defined as:

$E V I=G \times \frac{\rho_{\text {NIR }}-\rho_{\text {red }}}{\rho_{\text {NIR }}+C_{1} \times \rho_{\text {red }}-C_{2} \times \rho_{\text {blue }}+L}$

where $\rho_{\text {NIR }}$ and $\rho_{\text {red }}$ are the surface bidirectional reflectance factors for MODIS bands $1(620-670 \mathrm{~nm})$ and $2(841-876 \mathrm{~nm}), C_{1}(=6)$, $C_{2}(=7.5)$ are the coefficients of the aerosol resistance term, which uses the blue band to correct for aerosol influences in the red band, $L(=1)$ is the canopy background adjustment that addresses non-linear differential radiant transfer through the canopy and $G$ (gain factor) $=2.5$. The EVI MODIS product synthesizes vegetation data for every 16-day period, and is available since February 2000 , with $250 \mathrm{~m}$ of spatial resolution. Data was acquired from the Institute of Surveying, Remote Sensing and Land Information (IVFL) of the University of Natural Resources and Applied Life Sciences (BOKU), Vienna, which provides smoothed EVI time series for the entire globe, at no charge. The smoothing (filtering) process is necessary to reduce the effect of data noise on the estimation of phenological trends (http://ivfl-info.boku.ac.at/index.php/eo-dataprocessing/dataprocess-global).

The spatial and temporal assessment of fire occurrence in the study area was based on the previous work of França and Ribeiro (2008), who mapped the incidence of burn scars in the SCNP and MP-EPA between 1984 and 2007. We updated their mapping by extending the temporal range to 2014, and reanalyzing the previously mapped areas with the inclusion of additional Landsat scenes. França and Ribeiro (2008) used Landsat 5 TM, Landsat 7 ETM+ and CCD CBERS-2 imagery, considering only two images per year, the first acquired during the middle of the dry season (July), and the second during the end of the dry season (October). For the present study, all cloud-free Landsat images acquired between June and December were used for mapping, covering the entire duration of the fire season (Fornazari et al., 2015). This expanded temporal range allowed us to detect early and late fires, and minimized the effects of cloud cover. We analyzed between 5 and 10 images for each year, depending on cloud-free image availability. SLC-off ETM+ images from 2012 were matched to MODIS MCD45 images as a mean to fill the gaps, using a simple overlay during image interpretation.

We determined the length of the fire season using the Aqua MODIS active fire product (MYD14) acquired from the Brazilian National Institute for Space Research (INPE, http://www.dpi.inpe. $\mathrm{br} /$ proarco/bdqueimadas/). This product uses a contextual algorithm to detect active fires that are burning at the time of satellite overpass, if relatively cloud-free conditions are present (Giglio et al., 2003). We evaluated fire season length for the entire state of Minas Gerais, for the period between 2007 and 2013. Fires were mainly observed throughout the dry season, between July and November, with a peak between in September and October, during the transition from dry to rainy season (Fornazari et al., 2015; Fig. 2).

\subsection{Reconstructing spatial and temporal patterns of fire occurrence}

We mapped burn scars by visual interpretation of false color composites of each Landsat image, followed by manual delineation at a fixed visualization scale (1:25000). Red-green-blue composites were created for each image, using bands $5(1550-1750 \mathrm{~nm})$, $4(760-900 \mathrm{~nm})$, and $3(630-690 \mathrm{~nm})$ of the TM/ETM+ sensors, and bands $6(1570-1650 \mathrm{~nm}), 5(850-880 \mathrm{~nm})$ and $4(640-670 \mathrm{~nm})$ from the OLI sensor, with fixed contrast levels for all images. The delineation of burned areas was possible due to the distinctive visual aspect of the burn scars, in relation to most land cover types. However, spectral similarity between burn scars and bare rock surfaces prevented the successful use of automated classification algorithms in this area.

We produced individual maps for each available image (223 dates), which were later consolidated into annual maps of burned area (31 maps). Total annual burned area was calculated from each 


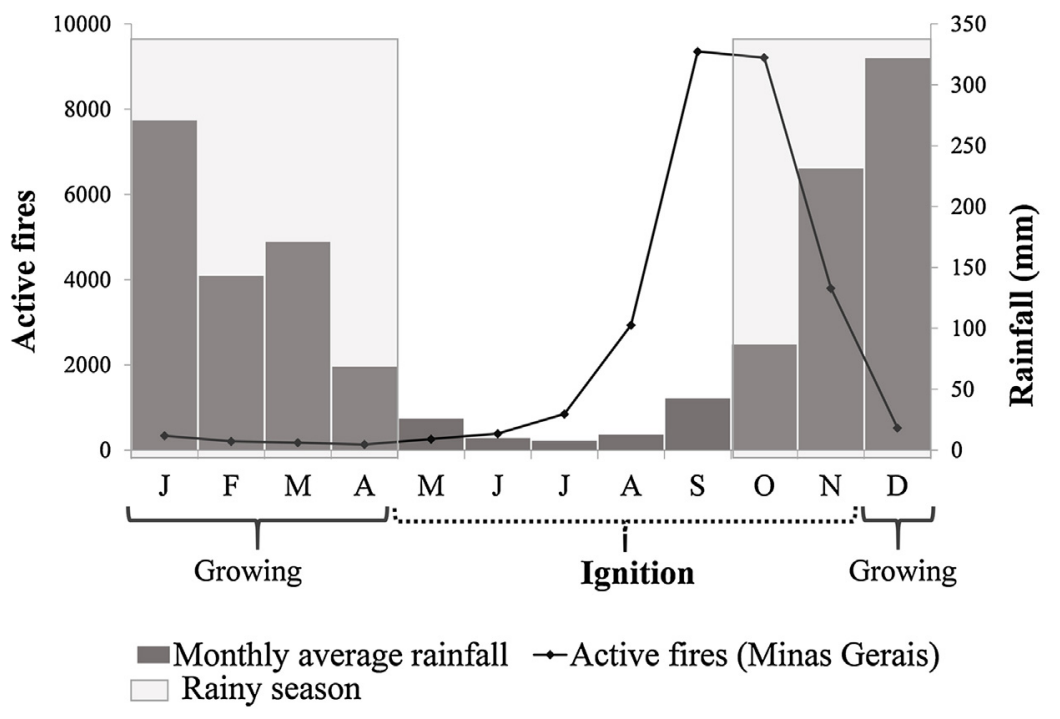

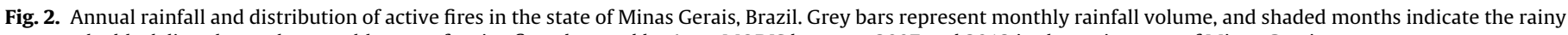
season; the black line shows the monthly sum of active fires detected by Aqua MODIS between 2007 and 2013 in the entire state of Minas Gerais.

annual map, and this information was used for statistical modeling (below). We also compared the number and size distribution of individually mapped scars among all annual maps, to identify possible changes in the nature of fire occurrences over time.

We produced three integrated descriptors of fire occurrence patterns for the entire studied period. First, we derived a single map of fire frequency spanning the 1984-2014 period, by converting each annual map into a binary raster image and then summing all maps. Second, we produced a map showing the time elapsed since the last observed fire, by successively overlapping annual fire maps for the 31 studied years. Time since the last fire can be seen as an indirect measure of fuel accumulation, important to determine fire risk and predict fire intensity. Finally, we derived a map of expected fire return intervals, calculated following the method by Wittkuhn and Hamilton (2010). The expected fire return interval was calculated for the entire studied period, as well as by decade: 1984-1993, 1994-2003 and 2004-2014, to assess possible changes in fire recurrence over time. Fire return intervals for the full 31 years were classified in four types: Very short ( $\mathrm{V}=$ burned every 1-2 years), Short ( $S=$ every $3-5$ years), Moderate $(M=$ every $6-10$ years) and Long ( $L=11$ years or more). The maps representing the spatial distribution of fire return interval per decade were further classified into different categories, due to the shorter time frames considered: Incomplete Fire Return Interval (single fire observed, last fire unknown or occurring in the previous decade); Single Fire Interval (burned only twice in a decade with a very short, short or moderate interval); Very Short Interval (more than two fires in a decade, with return time of 1-2 years), Mixed Interval (more than two fires in a decade, with varying return times) and Moderate Interval (fire returns every 3-5 years), also according to Wittkuhn and Hamilton (2010).

\subsection{Assessment of cloud cover effects on fire detection}

Our fire history reconstruction was affected by the presence of clouds, which can lead to underestimated fire frequencies and burned areas. To evaluate how cloud cover may have interfered with burn scar mapping (Appendix A), we used two separate approaches. First, we extracted cloud cover information from the fmask cloud mask band available for all Landsat CDR images used in the study. We then compared cloud cover frequency to the frequency of burned areas through visual analysis, as well as by calculation of the Spearman coefficient of correlation. Second, we estimated how long a burn scar is observable along consecutive images, as a proxy for scar detection probability under changing cloud cover. Throughout the series, we identified and tracked a total of 441 burn scars over time, noting if their observation was interrupted by cloud cover, and if not, for how many consecutive images were the scars observable (Fornazari et al., 2015).

We observed frequent cloud occurrence in the SCNP, with a pattern of higher frequency in the eastern portion of the study area. This area of increased cloudiness coincides with areas of lower fire frequency in some places, but not systematically. In total, $54 \%$ of the 442 tracked scars were affected by cloud presence, which prevented the assessment of their duration from fire onset to total disappearance. The remaining 203 scars were tracked without obstruction, most of them being observable in one or two consecutive images during the wet season (i.e. up to 30 days), and up to five consecutive images during the dry season (i.e. $>60$ days). Permanence was weakly correlated with burn scar size $(r=0.14, p$ $>0.05)$ and precipitation $(r=0.14, p<0.05)$. These results suggest that the total burned area mapped for each year may be slightly underestimated due to cloud cover, particularly in the eastern side of the protected area. Still, we are confident that most fires were detected, as all scars were observable for at least 2 months after fire.

\subsection{Data analysis}

We expressed annual rainfall as both the sum of monthly precipitated volume $(\mathrm{mm})$ from December to November of the next year (e.g. annual rainfall in 1984 was calculated from December 1983 to November 1984) and the number of rainy days observed for each seasonal year, presenting rainfall volume and rainfall temporal distribution, respectively. We further partitioned these representations of annual rainfall into two separate variables, reflecting the two main seasonal periods: growing season rainfall (December to April) and ignition season rainfall (May to November) (Fig. 2). Our rationale is that growing season rainfall mainly determines the amount of biomass produced, and therefore the amount of fuel available for burning, while rainfall during the ignition season determines the dryness of the existing fuel, and therefore the probability of ignition. Given the heterogeneity of the cerrado landscape, we also used the Enhanced Vegetation Index (EVI) as an indicator of 
vegetation type, by calculating the mean of the maximum per-pixel EVI values for each growing season, restricted to the areas mapped as burned during the following ignition season.

\subsubsection{Standardized precipitation index (SPI)}

We used the Standardized Precipitation Index (SPI) to characterize interannual rainfall variability in the region. SPI has been developed primarily for defining and monitoring drought, and is based on the cumulative probability of a given rainfall event occurring at a gauging station (McKee et al., 1993). Positive values of SPI indicate higher than expected precipitation, while negative values indicate lower than expected precipitation. SPI can be discretized into a classification from extremely wet to extremely dry events, and calculated at different time scales, based on the accumulated rainfall for different time periods (e.g; 3 months, 6 months, 12 months and 24 months). For the present study, we calculated SPI for the growing season (SPI - 5 months) and for the ignition season (SPI - 7 months), to determine the relative dryness of each consecutive season.

\subsubsection{Linear models and input variables}

We modeled the inter-annual variation of burned area as driven by rainfall and EVI (biomass), separated as growing season and ignition season rainfall. First, we formulated one simple linear regression model to test the relationship between burned area and mean annual rainfall (Table 2 ). Since precipitated volume was highly correlated with the number of rainy days $\left(r_{\text {annual }}=0.81\right.$, $r_{\text {growingseason }}=0.86, r_{\text {ignitionseason }}=0.76$ ), each representation of precipitation was included separately in each model formulation (Eq. (1) and Eq. (2)).

\section{Hypothesis 1}

Annual variation in rainfall volume or rainfall temporal distribution explains burned area.

Burned Area $=\beta_{0}+\beta_{1} \times$ Annual rainfall

Burned Area $=\beta_{0}+\beta_{1} \times$ Total number of days of rain

Where $\beta_{0}$ is the $y$-intercept model coefficient and $\beta_{1}$ is the slope model coefficient. Second, since growing and ignition season precipitation can be considered to be independent (Pearson's $r=-0.07$ for precipitated volume and $r=0.07$ for number of rainy days), we formulated three multiple regression models combining the amount of rain in the growing and ignition season (Eq. (3)), the number of days of rain in the growing and ignition season (Eq. (4)), and the number of days of rain in the growing and ignition season together with EVI values (Eq. (5)) (Table 2). We used Akaike's Information Criterion (AIC) to select the best model(s) (Burnham and Anderson, 2002).

\section{Hypothesis 2}

Rainfall volume precipitated during each season could have different effects on the burned area (growing season: higher rainfall $=$ higher biomass $=$ higher fuel availability = larger burned areas; ignition season: lower rainfall = drier biomass = higher ignition probability = larger burned areas).

$$
\begin{aligned}
& \text { Burned Area }=\beta_{0}+\beta_{1} \times \text { Growing season rainfall }+\beta_{2} \\
& \quad \times \text { Ignition season rainfall }
\end{aligned}
$$

\section{Hypothesis 3}

The seasonal distribution of rainfall (number of days of rain in each season, as indicator of seasonality) could have different effects on the burned area.

Burned Area $=\beta_{0}+\beta_{1} \times$ number of days of rain in the growing season $+\beta_{2} \times$ number of days

of rain in the ignition season

\section{Hypothesis 4}

The effect of seasonal rainfall volume or seasonal distribution of rainfall could have different effects over total burned area according to the vegetation type.

$$
\begin{gathered}
\text { Burned Area }=\beta_{0}+\beta_{1} \times \text { number of days of rain in the } \\
\text { growing season }+\beta_{2} \times \text { number of days of } \\
\text { rain in the ignition season }+\beta_{3} \times \text { EVI }
\end{gathered}
$$

Burned Area $=\beta_{0}+\beta_{1} \times$ growing season rainfall

$$
\begin{aligned}
& +\beta_{2} \times \text { ignition season rainfall } \\
& +\beta_{3} \times E V I
\end{aligned}
$$

Distributional assumptions for the regression models were tested using the Kolmogorov-Smirnov test. Homoscedasticity was confirmed and the statistical independence of the errors was confirmed by the Durbin-Watson test.

\section{Results}

\subsection{Spatial and temporal patterns of fire occurrence}

Our reconstruction of fire history in the Serra do Cipó National Park (SCNP) and Morro da Pedreira Environmental Protection Area (MP-EPA) showed that $983 \mathrm{~km}^{2}$ (75\% of the entire study area, Fig. 3a) have been burned at least once between 1984 and 2014, of which $283 \mathrm{~km}^{2}$ were burned within the SCNP (90\%) and $699 \mathrm{~km}^{2}$ within the MP-EPA (70\%). We observed strong spatial and temporal variation in fire occurrence across both protected areas. In terms of fire frequency, $51 \%$ of all burned areas were burned between one and four times, $22 \%$ between five and nine times, and $2 \%$ were burned ten times or more, from 1984 to 2014 (Fig. 3b).

We identified a pattern of lower fire frequency in the eastern side of the studied area, which is characterized by a higher density of woody vegetation (Fig. 3). Temporally, we also observed that a third of the studied area, mainly in the northwest region, was burned within the past five years (34\%), with fewer areas showing longer times since last burning (Fig. 4). Half of the study area was last burned between 1 and 15 years ago (53\%), while less than a quarter was last burned between 16 and 31 years ago (21\%, mainly in the southeast region).

Areas with very short fire return intervals had the highest frequency (48\%), and long return intervals had the lowest (4\%) frequency (Fig. 5). We did not observe a difference in fire return intervals between 1984-1993 and 1994-2003, where Very Short return intervals had the highest frequency (78\%). However, there was a general reduction in total area burned, as well as a reduction in the frequency of very short return intervals, for the 2004-2014 period, suggesting that the cerrado at Serra do Cipó is burning less frequently now than it did in the 1980s.

The spatial distribution of changes in fire return intervals across time showed a reduction in the number of individual burned scars for the SCNP in relation to the MP-EPA (Fig. 6), for the last decade. We also observed that while the number of burn scars decreased over time, mean and maximum scar size increased (Appendix B). 
a)

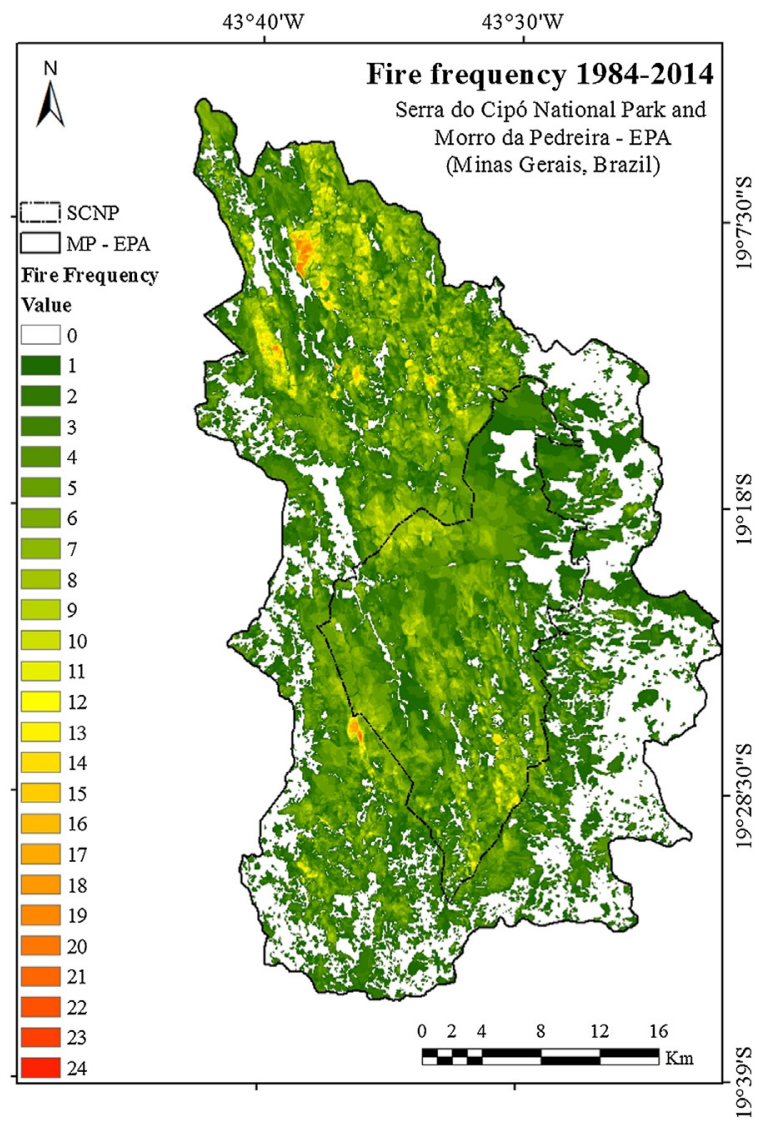

b)

\section{Fire Frequency Distribution}

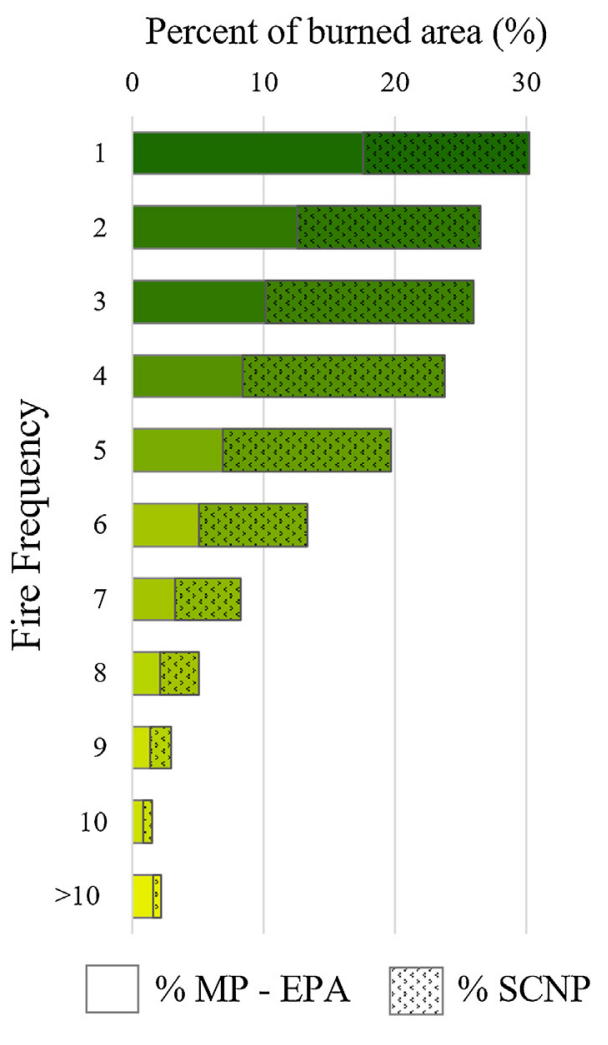

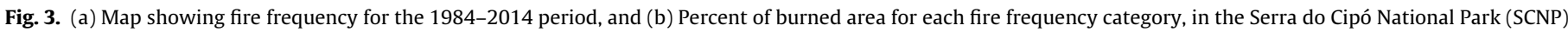

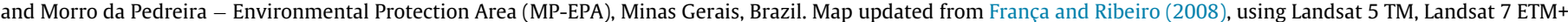
and Landsat 8 OLI images. Fire frequencies higher than 10 were summed together in the bar graph.

\subsection{Burned areas and the standardized precipitation index (SPI)}

Annual burned area showed strong interannual variation during the studied period (Fig. 7). The year with the largest burned area was $1993\left(329 \mathrm{~km}^{2}\right)$, while the lowest burned area was observed in $2013\left(18 \mathrm{~km}^{2}\right)$. SPI values calculated for the ignition and growing seasons were negatively correlated with annual burned area (Pearson's $\mathrm{r}=-0.40, \mathrm{p}=0.02$ and $\mathrm{r}=-0.11, \mathrm{p}=0.6$, respectively). Years with the largest burned area had moderately dry to very dry ignition SPI values, and near to normal to very dry growing SPI (Fig. 7). In contrast, years with the lowest burned area had both SPI values classified as nearly normal to moderately wet (Fig. 7).

\subsection{Linear models of burned area versus precipitation}

Total annual rainfall explained only $9 \%$ of the variation in annual burned area, showing a weak negative correlation (Pearson's $r=-0.29, p=0.11$ ). All regression models using the number of rainy days resulted in higher coefficients of determination than models using rainfall volume (Table 2 ). When the variables were combined using multiple regression models, the model including "number of rainy days in the growing season" and "number of rainy days in the ignition season" explained $38 \%$ of the variation in annual burned area (Table 2). Our best model included both the seasonal distribution of rainfall and EVI as an indicator of vegetation type, and showed the best explanatory power even with a lower number of observations (Table 2). The inclusion of EVI increased the percent of explained variance from $38 \%$ to $43 \%$, in relation to the previous model. However, AIC values are not comparable with the remain- ing models, due to the smaller number of observations available for EVI.

\section{Discussion}

Despite the protected status of the studied areas, the percentage of burned area remained high during the 31 years of study. The Serra do Cipó National Park was established in 1984, so we could not determine fire frequency or annual burned areas prior to this date, to evaluate the impact of conservation measures on the fire regime (França and Ribeiro, 2008). However, the Morro da Pedreira Environmental Protected Area was established in 1990, and for two years after its creation we did observe a slight reduction in total burned area. In Brazilian protected areas, the prevalent policy of maximum fire suppression often results in the occurrence of episodic severe wildfires, as fuel is accumulated over longer periods (long fire return intervals) (Durigan and Ratter, 2016). These fires are much more intense than regular fires, and very hard to control, resulting in extensive burning, as observed for 2014 in the studied area. According to Brazilian legislation, National Parks allow research and conservation activities, but prohibit other human activities such as livestock grazing (Rylands and Brandon, 2005). However, Pivello and Coutinho (1992) show that human-caused fires are much more frequent than natural fires in most cerrado parks and reserves, originating from nearby farms or urban areas. In the Serra do Cipó region, the extra protection after the establishment of the Morro da Pedreira Environmental Protected Area, and consequent livestock declines in the surrounding areas, may have 
a)

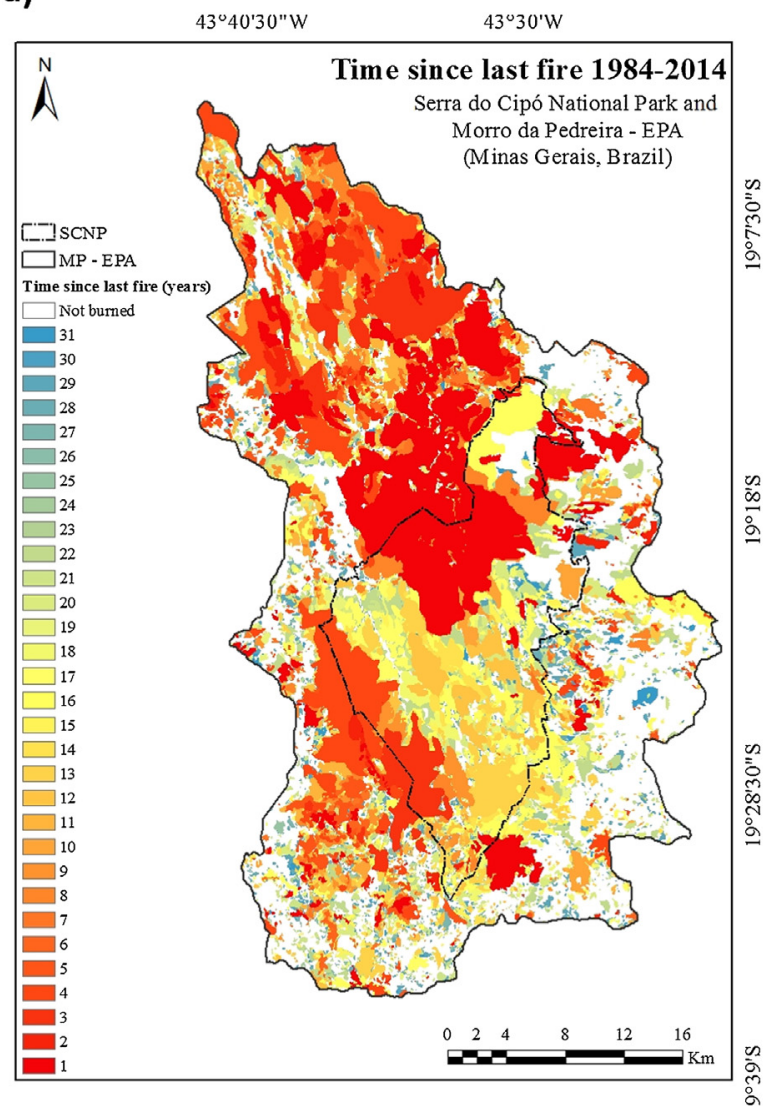

b)

\section{Time since last fire}

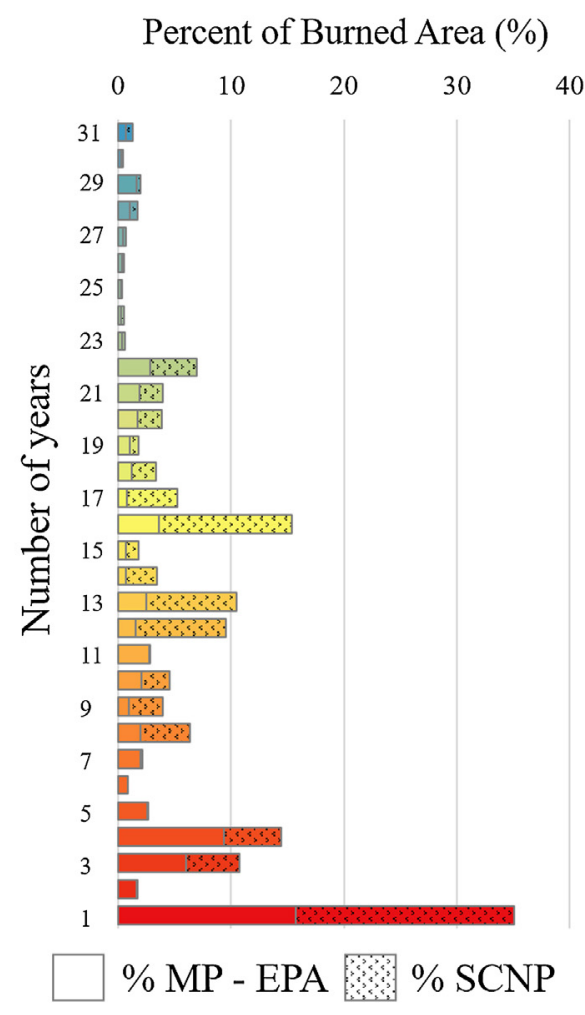

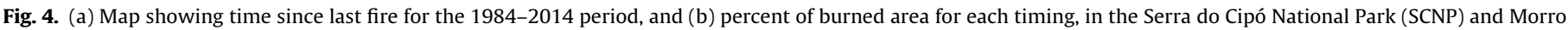
da Pedreira - Environmental Protection Area (MP-EPA), Minas Gerais, Brazil.

favored fuel buildup, explaining the observed increase in large fire occurrences over time in the protected areas (Appendix B).

The prevalence of low and moderate fire frequencies across the Serra do Cipó landscape configures a mosaic of burned areas differing in frequency, intensity, and seasonality, which suggests a high fire recovery potential for this complex vegetation system. At Serra do Cipó, fire recovery times have been related to the diversity of vegetation types with variable proportions of woody plants (Silveira et al., 2016; Fernandes, 2016), corroborating our observed improvements in model performance when including a proxy for woody cover (EVI). The negative relation between burned area and EVI can be explained by the spatial distribution of cerrado/woodland/forest vegetation at Serra do Cipó. We believe that the correlation between lesser burned area and higher EVI values captures the low fire frequency expected for vegetation types with denser tree cover (woodlands and forests), which are known to be less flammable (Hoffmann et al., 2012a). The existence of vegetation patches with different fire histories can also favor the diversity of potential seed sources (seeder species) and/or autogenic regrowth species (sprouter species) able to support recolonization of burned areas (Hodgkinson, 1998; Keeley, 1977; Pausas et al., 2004). This has been reported as necessary to maintain the diversity of light-dependent, fire-prone species and woodland savanna species (Ramos-Neto and Pivello, 2000), allowing alternative states of cerrado vegetation to coexist (Dantas et al., 2016; Hoffmann et al., 2012a; Pausas, 2015; Staver et al., 2011). This effect can be favored by managing fire-prone ecosystems, using prescribed fires to allow natural regeneration and reduce the negative effects of extended and severe fires (Bloesch, 1999; Boer et al., 2009; Pivello and Norton, 1996; Weber and Taylor, 1992).
The timing of fire occurrence is also relevant to determine the damages to leafing, flowering, fruiting and/or germination processes, impacting seedlings and reducing recruitment, as well as favoring specific groups of species that are fire tolerant or fire resistant (Alvarado et al., 2015, 2014; Hoffmann, 1998). The peak in active fires, observed on MODIS data from Serra do Cipó between the end of the dry season and the beginning of the wet season (September and October), is consistent with other cerrado studies. This timing suggests a higher impact of later fires on vegetation, as these fires are hotter and more difficult to control (Ramos-Neto and Pivello, 2000). The peaking of burned areas in the transition between the dry to wet seasons has also been reported by RamosNeto and Pivello (2000) for the Emas National Park (Goiás, Brazil). They associate the higher frequency of burned areas in September and October to increased lightning from the storms that characterize this transitional season, while the vegetation is still able to carry a fire. On the contrary, early fires during the transition from wet to dry season (April and May) or early dry season (May and June) had a low frequency of occurrence at Serra do Cipó. In contrast with late dry season fires, early fires tend to be colder and less severe, burning patchily (Ramos-Neto and Pivello, 2000) since the accumulated fuel will have higher moisture levels. Both early and late fires have been observed for lowland cerrado (Coutinho, 1990; Miranda et al., 2009; Mistry and Bizerril, 2011) and other savannas across the world (Govender et al., 2006; Knapp et al., 2004 Knapp et al., 2004).

The 38\% variation in annual burned area across Serra do Cipó was explained by seasonality (number of rainy days in the growing season versus the ignition season) and is consistent with African savannas, where rainfall amount and seasonality explained $40 \%$ of 
a)

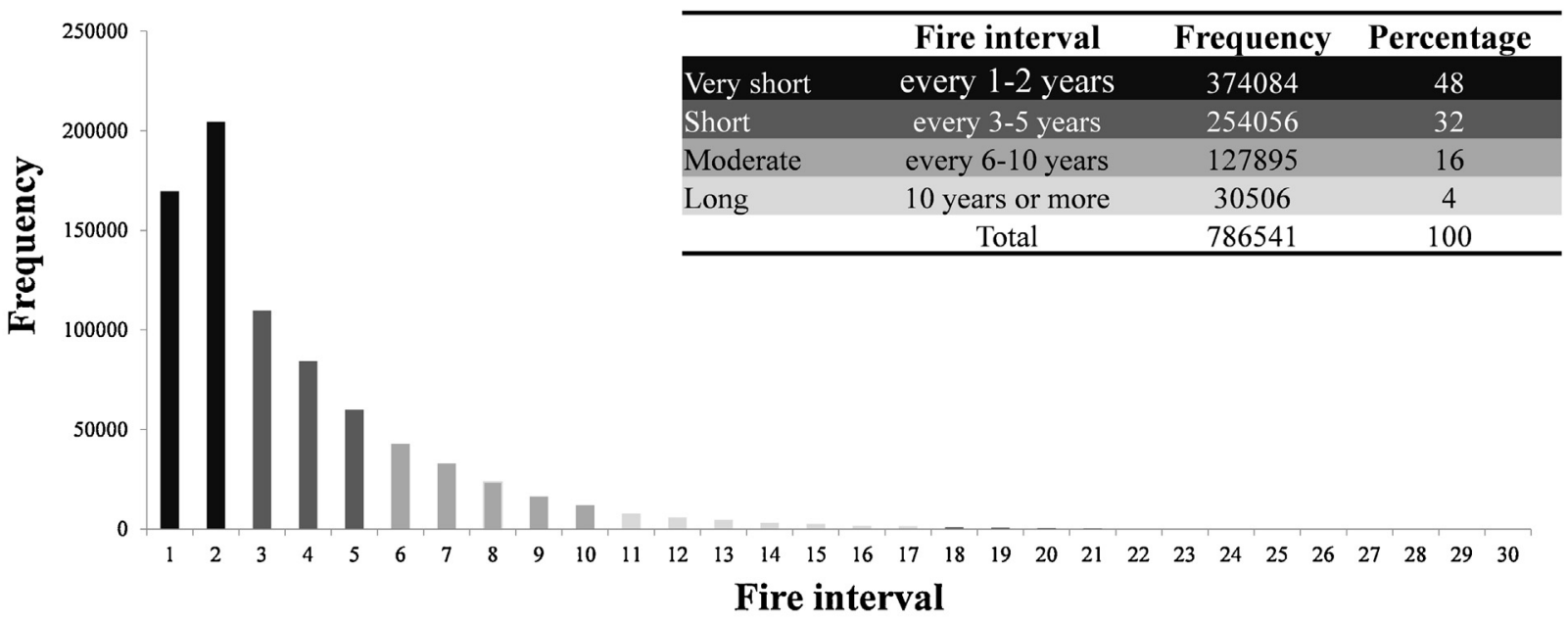

b)

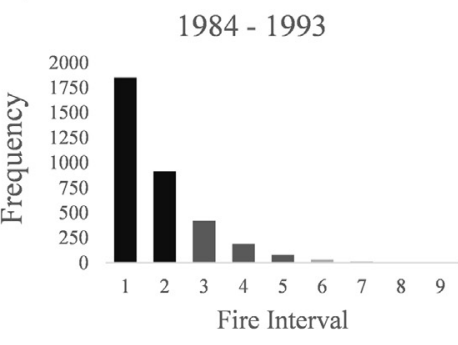

\begin{tabular}{lcc}
\hline & Frequency & Percentage \\
Very short & 2764 & 78.9 \\
Short & 689 & 19.7 \\
Moderate & 49 & 1.4 \\
Long & 0 & 0 \\
& 3502 & 100 \\
\hline
\end{tabular}

c)

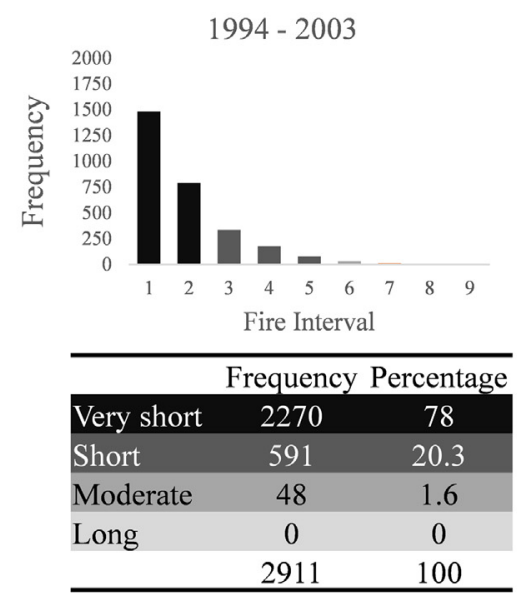

d)

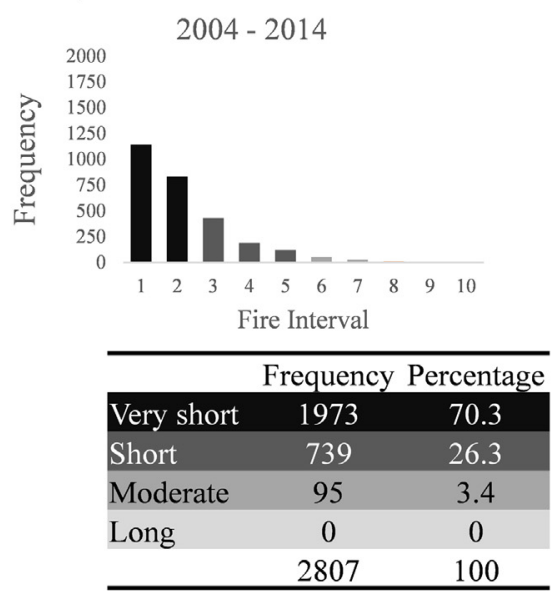

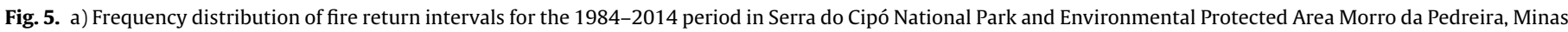

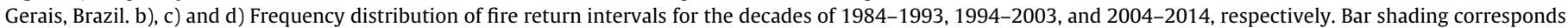
to each shaded interval type on the tables.

the variance in burned area (Archibald et al., 2010). This variation in burned area over time has been attributed to changes in grass fuel availability, affected in turn by inter-annual rainfall variation (Aldersley et al., 2011; Archibald et al., 2009; van der Werf et al., 2008). Thus, we expected a higher contribution of annual rainfall volume to explain annual burned area at Serra do Cipó. Our models, however, showed a higher importance of seasonality, in the form of temporal rainfall distribution (number of rainy days in each season), over rainfall amount, and the severity of dryness during the ignition season as the best explanation for fire occurrence in Serra do Cipó cerrados. In contrast, for the more arid African savannas, seasonality has been shown to be secondary to rainfall amount, which acts as the main driver and is positively correlated with burned area (Archibald et al., 2010). Thus, monitoring moisture levels during the ignition season could allow managers to predict potential fire risk for the Serra do Cipó landscape.

Finally, we confirm that fire occurrence depends on different drivers according to the type of savanna, strongly implying that savannas across the world will respond differently to changes in the fire regime, either from direct human impacts or as a result of changes in future climatic conditions. Our study site is dominated by wet savannas (mean annual rainfall $>1000 \mathrm{~mm}$ ) and our result was consistent with patterns observed for wet savannas in Africa
(Northern Angola, Democratic Republic of Congo, Madagascar and Northern Mozambique), where there is no correlation between burned area and rainfall volume, only with seasonality (Archibald et al., 2010). In contrast, for African dry savannas (mean annual rainfall $<1000 \mathrm{~mm}$ ) there is a positive correlation between annual rainfall volume and burned area (Archibald et al., 2010). Our results show that fire occurrence in the Serra do Cipó region is moisturedependent, instead of fuel-dependent, where high rainfall levels increase primary productivity and biomass recovery, and prevent fuel availability from being a limiting factor. The length and the distribution of rain in the dry season, on the other hand, will determine fuel moisture levels and thus ignition probability, increasing fire occurrence during the driest conditions. This has been shown by global models of savanna vegetation dynamics across continents (Staver et al., 2011; van der Werf et al., 2008).

We observed a slight change in the fire regime for the 31 studied years. The consequences of these changes must be better studied as they could favor bush encroachment, which has been shown for cerrado areas (Durigan and Ratter, 2016; Hoffmann, 1999) and other savannas (Roques et al., 2001; Wigley et al., 2009), and as fire suppression could affect the long-term recovery of grassland vegetation. Although we cannot determine fire sources for the Serra do Cipó landscape, we can hypothesize that fires observed within 


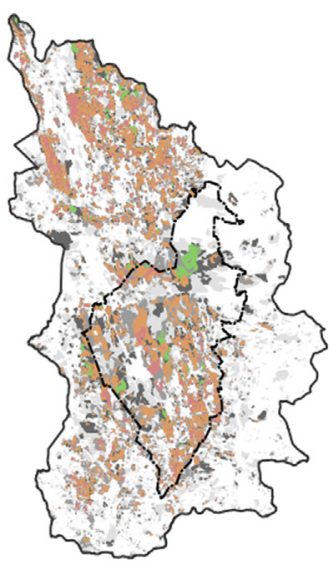

1984-1993

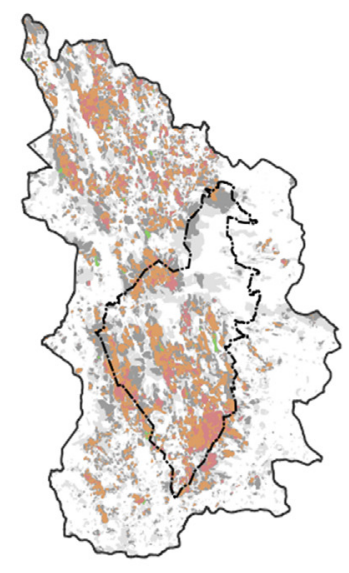

1994-2003

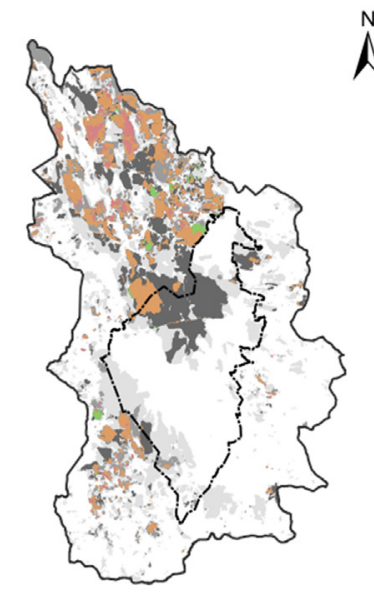

2004-2014

$\stackrel{N}{N}$

Incomplete fire return interval (burned once)

Single Fire interval (1-2 years or 3-5 years interval)

Single Fire interval ( $>6$ years)

Very short interval

Mixed interval

Moderate interval

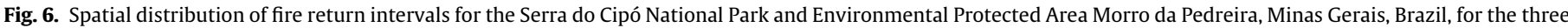

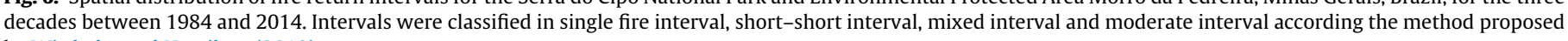
by Wittkuhn and Hamilton (2010).

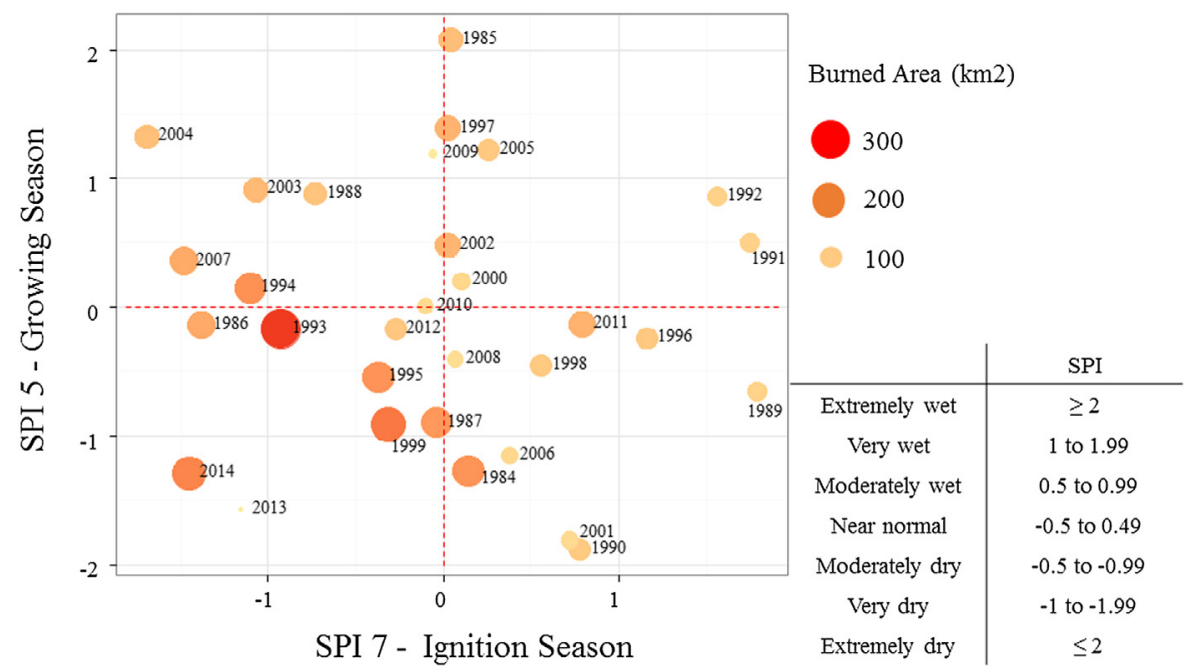

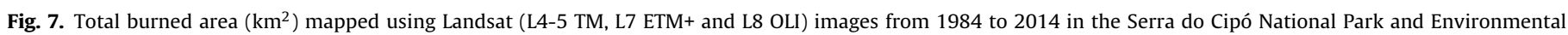

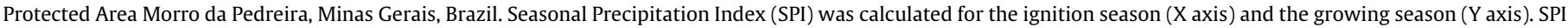
classification according to McKee et al. (1993).

the park were either originated from natural sources or spread from the Environmental Protection Area, since there is no human occupation inside the park and management enforces a fire suppression policy. Agriculture and livestock ranging are still allowed within the The Morro da Pedreira Environmental Protection Area, employing the usual slash-and-burn management with humanoriginated fires occurring mostly during the dry season (May to September) (Coutinho, 1990; Klink and Moreira, 2002). Therefore, we can observe, at the landscape scale, that fire consumes the fuel and burns in patches that may act as firebreaks to unburned areas. This way, human-managed burning should be considered as an important tool to avoid the spread of wildfires (Ramos-Neto and Pivello, 2000), maintaining low fuel levels to be burned by natu- ral fires. These interactions between fire and human management should be considered for the management of protected areas at Serra do Cipó, and likely cerrado protected areas elsewhere.

\section{Acknowledgments}

S.T. Alvarado received postdoctoral support from grant \#035/016/13 (PROPe/CDC/UNESP), São Paulo State University, and from grant \#2014/12728-1, São Paulo Research Foundation (FAPESP). This research was also supported by FAPESP - Microsoft Research Foundation grant \#2013/50155-0. T.S.F. Silva and L. P. C Morellato receive research productivity grants from the National Council for Scientific and Technological Development CNPq, grants 
\#310144/2015-9 and \#310761/2014-0, respectively. We thank the Parque Nacional da Serra do Cipó for the permit to work at the park, the Cedro Company and Reserva Vellozia for the permit to work on their private land, and their staff for the support. We are grateful to Helena França for providing the original mapping data, to Dr. André Lima and Jefferson Ferreira-Ferreira for the invaluable help during mapping, and to Dr. Sally Archibald for comments that improved this manuscript.

\section{Appendix A-B Supplementary data}

Supplementary data associated with this article can be found, in the online version, at http://dx.doi.org/10.1016/j.ecolind.2017. 02.037 .

\section{References}

Aldersley, A., Murray, S.J., Cornell, S.E., 2011. Global and regional analysis of climate and human drivers of wildfire. Sci. Total Environ. 409, 3472-3481, http://dx.doi.org/10.1016/j.scitotenv.2011.05.032.

Alvarado, S.T., Buisson, E., Rabarison, H., Rajeriarison, C., Birkinshaw, C., Lowry II, P.P., Morellato, L.P.C., 2014. Fire and the reproductive phenology of endangered Madagascar sclerophyllous tapia woodlands. South Afr. J. Bot. 94, 79-87, http://dx.doi.org/10.1016/j.sajb.2014.06.001.

Alvarado, S.T., Buisson, E., Rabarison, H., Rajeriarison, C., Birkinshaw, C., Lowry II, P.P., 2015. Effects of heat on the germination of sclerophyllous forest species in the highlands of Madagascar. Aust. Ecol. 40, 601-610, http://dx.doi.org/10. $1111 /$ aec.12227.

Archibald, S., Roy, D.P., Wilgen, V., Brian, W., Scholes, R.J., 2009. What limits fire? An examination of drivers of burnt area in Southern Africa. Glob. Chang. Biol. $15,613-630$

Archibald, S., Nickless, A., Govender, N., Scholes, R.J., Lehsten, V., 2010. Climate and the inter-annual variability of fire in southern Africa: a meta-analysis using long-term field data and satellite-derived burnt area data. Glob. Ecol. Biogeogr. 19, 794-809.

Archibald, S., 2016. Managing the human component of fire regimes: lessons from Africa. Philos. Trans. R. Soc. Lond. B Biol. Sci. 371

Bloesch, U., 1999. Fire as a tool in the management of a savanna/dry forest reserve in Madagascar. Appl. Veg. Sci. 2, 117-124.

Boer, M.M., Sadler, R.J., Wittkuhn, R.S., McCaw, L., Grierson, P.F., 2009. Long-term impacts of prescribed burning on regional extent and incidence of wildfires-evidence from 50 years of active fire management in SW Australian forests. For. Ecol. Manage. 259, 132-142, http://dx.doi.org/10.1016/j.foreco. 2009.10.005.

Bond, W.J., Keeley, J.E., 2005. Fire as a global herbivore: the ecology and evolution of flammable ecosystems. Trends Ecol. Evol. 20, 387-394.

Bond, W.J., Woodward, F.I., Midgley, G.F., 2005. The global distribution of ecosystems in a world without fire. New Phytol. 165, 525-538.

Bradstock, R.A., 2010. A biogeographic model of fire regimes in Australia: current and future implications. Glob. Ecol. Biogeogr. 19, 145-158, http://dx.doi.org/ 10.1111/j.1466-8238.2009.00512.x.

Burnham, K.P., Anderson, D.R., 2002. Model Selection and Multi-model Inference: A Practical Information-Theoretic Approach. Springer.

Cochrane, M.A., Ryan, K.C., 2009. Fire and fire ecology: concepts and principles. In Springer Praxis Books. Springer, Berlin Heidelberg, pp. 25-62.

Coutinho, L.M., 1982. Ecological effects of fire in brazilian cerrado. In: Huntley, B.J., Walker, B.H. (Eds.), Ecological Studies. Springer, Berlin Heidelberg, pp. 273-291.

Coutinho, L.M., 1990. Fire in the ecology of the brazilian cerrado. In: Goldammer, D.J.G. (Ed.), Ecological Studies. Springer, Berlin Heidelberg, pp. 82-105.

Csiszar, I., Justice, C.O., Mcguire, A.D., Cochrane, M.A., Roy, D.P., Brown, F., Conard, S.G., Frost, P.G.H., Giglio, L., Elvidge, C., Flannigan, M.D., Kasischke, E., Mcrae, D.J., Rupp, T.S., Stocks, B.J., Verbyla, D.L., 2004. Land use and fires. In: Gutman, D.G., Janetos, A.C., Justice, C.O., Moran, D.E.F., Mustard, J.F., Rindfuss, R.R., Skole, D., Cochrane, B.L.T. (Eds.), Remote Sensing and Digital Image Processing. Springer, Netherlands, pp. 329-350.

Dantas, V., de, L., Pausas, J.G., Batalha, M.A., Loiola, P., de, P., Cianciaruso, M.V. 2012. The role of fire in structuring trait variability in Neotropical savannas. Oecologia 171, 487-494, http://dx.doi.org/10.1007/s00442-012-2431-8.

Dantas, V., de, L., Batalha, M.A., Pausas, J.G., 2013. Fire drives functional thresholds on the savanna-forest transition. Ecology 94, 2454-2463.

Dantas, V., de, L., Hirota, M., Oliveira, R.S., Pausas, J.G., 2016. Disturbance maintains alternative biome states. Ecol. Lett. 19, 12-19, http://dx.doi.org/10.1111/ele. 12537.

Durigan, G., Ratter, J.A., 2016. The need for a consistent fire policy for Cerrado conservation. J. Appl. Ecol. 53, 11-15, http://dx.doi.org/10.1111/1365-2664. 12559.

Durigan, G., Siqueira, M.F., de Franco, G.A.D.C., 2007. Threats to the Cerrado remnants of the state of São Paulo. Brazil. Sci. Agric. 64, 355-363, http://dx.doi. org/10.1590/S0103-90162007000400006.
Fernandes, G.W. (Ed.), 2016. Ecology and Conservation of Mountaintop Grasslands in Brazil. Springer International Publishing, Cham, http://dx.doi.org/10.1007/ 978-3-319-29808-5.

Fichino, B.S., Dombroski, J.R.G., Pivello, V.R., Fidelis, A., 2016. Does fire trigger seed germination in the Neotropical Savannas? Experimental Tests with Six Cerrado Species. Biotropica 48, 181-187, http://dx.doi.org/10.1111/btp.12276.

Fidelis, A., Blanco, C., 2014. Does fire induce flowering in Brazilian subtropical grasslands? Appl. Veg. Sci. 17, 690-699, http://dx.doi.org/10.1111/avsc.12098.

Fidelis, A., Daibes, L.F., Martins, A.R., Fidelis, A., Daibes, L.F., Martins, A.R., 2016. To resist or to germinate? The effect of fire on legume seeds in Brazilian subtropical grasslands. Acta Bot. Bras. 30, 147-151, http://dx.doi.org/10.1590/ 0102-33062015abb0187.

Fornazari, T., Silva, T.S.F., Alvarado, S.T., Morellato, L.P.C., 2015. Variáveis Limitantes Sobre a Detecção De Queimadas Em Imagens Landsat No Parque Nacional Da Serra Do Cipó (MG). João Pessoa, Pernambuco Brasil.

França, H., Ribeiro, K.T., 2008. Mapeamento de queimadas no Parque Nacional da Serra do Cipó e na Área de Proteção Ambiental Morro da Pedreira, MG: 1984-2007. Jaboticatubas, MG.

Giglio, L., Descloitres, J., Justice, C.O., Kaufman, Y.J., 2003. An enhanced contextual fire detection algorithm for MODIS. Remote Sens. Environ. 87, 273-282, http:// dx.doi.org/10.1016/S0034-4257(03)00184-6.

Giulietti, A.M., 1997. Espinhaço range region eastern Brazil. In: Centres of Plant Diversity: A Guide and Strategy for Their Conservation., pp. 397-404, http://dx. doi.org/10.2307/3060192.

Gorgone-Barbosa, E., Pivello, V.R., Bautista, S., Rissi, M.N., Zupo, T., Galdi, J., Zirondi, H., Fidelis, A., 2013. Does the presence of invasive grasses affect fire behavior and severity in Brazilian tropical savannas? Symp. Int. Assoc. Veg. Sci. IAVS, 56.

Gorgone-Barbosa, E., Pivello, V.R., Baeza, M.J., Fidelis, A., 2016. Disturbance as a factor in breaking dormancy and enhancing invasiveness of African grasses in a Neotropical Savanna. Acta Bot. Bras. 30, 131-137, http://dx.doi.org/10.1590/ 0102-33062015abb0317.

Govender, N., Trollope, W.S.W., Van Wilgen, B.W., 2006. The effect of fire season, fire frequency, rainfall and management on fire intensity in savanna vegetation in South Africa. J. Appl. Ecol. 43, 748-758, http://dx.doi.org/10. 1111/j.1365-2664.2006.01184.x.

Hodgkinson, K.C., 1998. Sprouting success of shrubs after fire: height-dependent relationships for different strategies. Oecologia 115, 64-72, http://dx.doi.org/ 10.1007/s004420050492.

Hoffmann, W.A., Adasme, R., Haridasan, M., de Carvalho, T., Geiger, M., Pereira, E.L. Gotsch, M.A.B., Franco, S.G., 2009. Tree topkill, not mortality, governs the dynamics of savanna-forest boundaries under frequent fire in central Brazil. Ecology 90, 1326-1337, http://dx.doi.org/10.1890/08-0741.1.

Hoffmann, W.A., Geiger, E.L., Gotsch, S.G., Rossatto, D.R., Silva, L.C.R., Lau, O.L., Haridasan, M., Franco, A.C., 2012a. Ecological thresholds at the savanna-forest boundary: how plant traits, resources and fire govern the distribution of tropical biomes. Ecol. Lett. 15, 759-768, http://dx.doi.org/10.1111/j.14610248.2012.01789.x.

Hoffmann, W.A., Jaconis, S.Y., Mckinley, K.L., Geiger, E.L., Gotsch, S.G., Franco, A.C., 2011. Fuels or microclimate? Understanding the drivers of fire feedbacks at savanna-forest boundaries. Aust. Ecol., 634-643.

Hoffmann, W.A., 1998. Post-burn reproduction of woody plants in a neotropical savanna: the relative importance of sexual and vegetative reproduction. J. Appl. Ecol. 35, 422-433, http://dx.doi.org/10.1046/j.1365-2664.1998.00321.x.

Hoffmann, W.A., 1999. Fire and population dynamics of woody plants in a neotropical savanna: matrix model projections. Ecology 80, 1354-1369, http:// dx.doi.org/10.1890/0012-9658(1999)080[1354:FAPDOW]2.0.CO;2.

Hudak, A.T., Brockett, B.H., 2004. Mapping fire scars in a southern African savannah using Landsat imagery. Int. J. Remote Sens. 25, 3231-3243, http://dx.doi.org/ 10.1080/01431160310001632666.

Keeley, J.E., 1977. Seed production, seed populations in soil, and seedling production after fire for two congeneric pairs of sprouting and nonsprouting chaparal shrubs. Ecology 58, 820-829.

Klink, C.A., Moreira, A.G., 2002. Past and current human occupation, and land use. Cerrados Bras. Ecol. Nat. Hist. a Neotrop. Savanna, 69-90.

Knapp, A.K., Smith, M.D., Collins, S.L., Zambatis, N., Peel, M., Emery, S., Wojdak, J., Horner-Devine, M.C., Biggs, H., Kruger, J., Andelman, S.J., 2004. Generality in ecology: testing North American grassland rules in South African savannas. Front. Ecol. Environ. 2, 483-491, http://dx.doi.org/10.1890/15409295(2004)002[0483:GIETNA]2.0.CO;2.

Krawchuk, M.A., Moritz, M.A., 2011. Constraints on global fire activity vary across a resource gradient. Ecology 92,121-132

Lehmann, C.E.R., Archibald, S.A., Hoffmann, W.A., Bond, W.J., 2011. Deciphering the distribution of the savanna biome. New Phytol. 191, 197-209, http://dx.doi. org/10.1111/j.1469-8137.2011.03689.x.

Lehmann, C.E., Anderson, T.M., Sankaran, M., Higgins, S.I., Archibald, S., Hoffmann, W.A., Hanan, N.P., Williams, R.J., Fensham, R.J., Felfili, J., 2014. Savanna vegetation-fire-climate relationships differ among continents. Science 80 (343), 548-552.

Liu, H.Q., Huete, A., 1995. Feedback based modification of the NDVI to minimize canopy background and atmospheric noise. IEEE Trans. Geosci. Remote Sens. 33, 457-465, http://dx.doi.org/10.1109/36.377946.

Loiola, P., de, P., Cianciaruso, M.V., Silva, I.A., Batalha, M.A., 2010. Functional diversity of herbaceous species under different fire frequencies in Brazilian savannas. Flora Morphol. Distrib. Funct. Ecol. Plants 205, 674-681, http://dx. doi.org/10.1016/j.flora.2010.04.006. 
McKee, T.B., Doesken, N.J., Kleist, J., others, 1993. The Relationship of Drought Frequency and Duration to Time Scales. American Meteorological Society Boston, MA, USA, pp. 179-183.

Meyn, A., White, P.S., Buhk, C., Jentsch, A., 2007. Environmental drivers of large, infrequent wildfires: the emerging conceptual model. Prog. Phys. Geogr. 31, 287-312, http://dx.doi.org/10.1177/0309133307079365.

Miranda, H.S., Sato, M.N., Neto, W.N., Aires, F.S., 2009. Fires in the cerrado, the Brazilian savanna. In: Springer Praxis Books. Springer, Berlin Heidelberg, pp. 427-450.

Mistry, J., Bizerril, M., 2011. Why it is important to understand the relationship between people, fire and protected areas. Biodiversidade Bras. 1, 40-49.

Oliveira-Filho, A.T., Ratter, J.A., 2002. Vegetation physiognomies and woody flora of the cerrado biome. In: The Cerrados of Brazil: Ecology and Natural History of a Neotropical Savanna., pp. 91-120.

Overbeck, G.E., Vélez-Martin, E., Scarano, F.R., Lewinsohn, T.M., Fonseca, C.R., Meyer, S.T., Müller, S.C., Ceotto, P., Dadalt, L., Durigan, G., Ganade, G., Gossner, M.M., Guadagnin, D.L., Lorenzen, K., Jacobi, C.M., Weisser, W.W., Pillar, V.D., 2015. Conservation in Brazil needs to include non-forest ecosystems. Divers. Distrib. 21, 1455-1460, http://dx.doi.org/10.1111/ddi.12380.

Pausas, J.G., Bradstock, R.A., Keith, D.A., Keeley, J.E., 2004. Plant functional traits in relation to fire in crown-fire ecosystems. Ecology 85, 1085-1100.

Pausas, J.G., 2015. Alternative fire-driven vegetation states. J. Veg. Sci. 26, 4-6, http://dx.doi.org/10.1111/jvs.12237.

Pivello, V.R., Coutinho, L.M., 1992. Transfer of macro-nutrients to the atmosphere during experimental burnings in an open cerrado (Brazilian savanna). J. Trop. Ecol. 8, 487-497.

Pivello, V.R., Norton, G.A., 1996. FIRETOOL: an expert system for the use of prescribed fires in Brazilian savannas. J. Appl. Ecol. 33, 348-356.

Pivello, V.R., 2005. Manejo de fragmentos de Cerrado: princípios para a conservação da biodiversidade. SCARIOT, A.; SOUSA-SILVA, J.C.; FELFILI, J.M. (Org.), Brasilia, pp. 401-413.

Ramos-Neto, M.B., Pivello, V.R., 2000. Lightning fires in a brazilian savanna national park: rethinking management strategies. Environ. Manage. 26, 675-684, http://dx.doi.org/10.1007/s002670010124.

Ratter, J.A., Ribeiro, J.F., Bridgewater, S., 1997. The Brazilian cerrado vegetation and threats to its biodiversity. Ann. Bot. 80, 223-230.

Ribeiro, M.C., Figueira, J.E.C., 2011. Uma abordagem histórica do fogo no Parque Nacional da Serra do Cipó: Minas Gerais-Brasil. Biodiversidade Bras., 212-227.

Roques, K. g., O'Connor, T. g., Watkinson, A. r., 2001. Dynamics of shrub encroachment in an African savanna: relative influences of fire, herbivory, rainfall and density dependence. J. Appl. Ecol. 38, 268-280, http://dx.doi.org/ 10.1046/j.1365-2664.2001.00567. x.

Russell-Smith, J., Ryan, P.G., Durieu, R., 1997. A LANDSAT MSS-derived fire history of kakadu national park, monsoonal northern australial 1980-94: seasonal extent, frequency and patchiness. J. Appl. Ecol. 34, 748-766, http://dx.doi.org $10.2307 / 2404920$.
Rylands, A.B., Brandon, K., 2005. Brazilian protected areas. Conserv. Biol. 19, 612-618, http://dx.doi.org/10.1111/j.1523-1739.2005.00711.x.

Silva, J.M.C., da Bates, J.M., 2002. Biogeographic patterns and conservation in the south american cerrado: a tropical savanna hotspot. Bioscience 52, 225, http:// dx.doi.org/10.1641/0006-3568(2002)052[0225:BPACIT]2.0.CO;2.

Silva, D.M., Batalha, M.A., Cianciaruso, M.V., 2013. Influence of fire history and soil properties on plant species richness and functional diversity in a neotropical savanna. Acta Bot. Bras. 27, 490-497.

Silveira, F.A.O., Negreiros, D., Barbosa, N.P.U., Buisson, E., Carmo, F.F., Carstensen, D.W., Conceição, A.A., Cornelissen, T.G., Echternacht, L., Fernandes, G.W., Garcia, Q.S., Guerra, T.J., Jacobi, C.M., Lemos-Filho, J.P., Stradic, S., Le Morellato, L.P.C., Neves, F.S., Oliveira, R.S., Schaefer, C.E., Viana, P.L., Lambers, H., 2016. Ecology and evolution of plant diversity in the endangered campo rupestre: a neglected conservation priority. Plant Soil 403, 129-152, http://dx.doi.org/10. 1007/s11104-015-2637-8.

Soares-Filho, B., Rajão, R., Macedo, M., Carneiro, A., Costa, W., Coe, M., Rodrigues, H., Alencar, A., 2014. Cracking Brazil's forest code. Science 344 (80).

Staver, A.C., Archibald, S., Levin, S.A., 2011. The global extent and determinants of savanna and forest as alternative biome states. Science 344 (80), 230-232, http://dx.doi.org/10.1126/science.1210465.

Trollope, W.S.W., Trollope, L.A., Hartnett, D.C., 2002. Fire Behaviour a Key Factor in the Fire Ecology of African Grasslands and Savannas. For. Fire Res. Wildl. Fire Safety. Viegas Mill Press.

Weber, M.G., Taylor, S.W., 1992. The use of prescribed fire in the management of Canada's forested lands. For. Chron. 68, 324-334, http://dx.doi.org/10.5558/ tfc68324-3.

White, R.P., Murray, S., Rohweder, M., Prince, S.D., Thompson, K.M., 2000. Pilot Analysis of Global Ecosystems: Grassland Ecosystems. World Resources Institute Washington, DC, USA.

Wigley, B.J., Bond, W.J., Hoffman, M.T., 2009. Bush encroachment under three contrasting land-use practices in a mesic South African savanna. Afr. J. Ecol. 47, 62-70, http://dx.doi.org/10.1111/j.1365-2028.2008.01051.x.

Wittkuhn, R.S., Hamilton, T., 2010. Using fire history data to map temporal sequences of fire return intervals and seasons. Fire Ecol. 6, 97-114.

Zhu, Z., Wang, S., Woodcock, C.E., 2015. Improvement and expansion of the Fmask algorithm: cloud, cloud shadow, and snow detection for Landsats 4-7, 8, and Sentinel 2 images. Remote Sens. Environ. 159 (8), 269-277, http://dx.doi.org/ 10.1016/j.rse.2014.12.014.

van der Werf, G.R., Randerson, J.T., Giglio, L., Gobron, N., Dolman, A.J., 2008. Climate controls on the variability of fires in the tropics and subtropics. Global Biogeochem. Cycles 22, GB3028, http://dx.doi.org/10.1029/2007GB003122. 